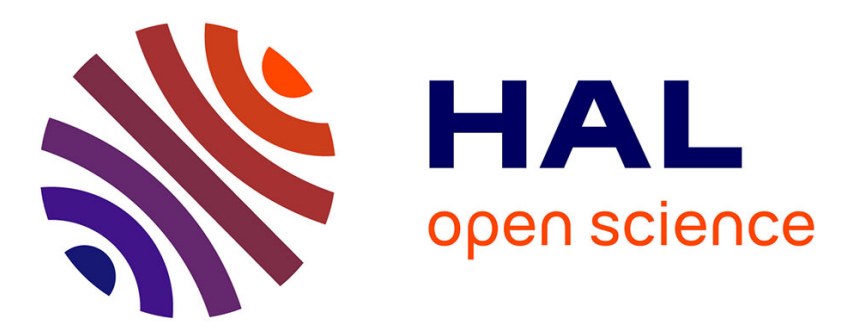

\title{
INFLUENCE OF ARSENIC VAPOR SPECIES ON ELECTRICAL AND OPTICAL PROPERTIES OF MBE GROWN GaAs
}

\author{
H. Jung, H. Künzel, K. Ploog
}

\section{- To cite this version:}

H. Jung, H. Künzel, K. Ploog. INFLUENCE OF ARSENIC VAPOR SPECIES ON ELECTRICAL AND OPTICAL PROPERTIES OF MBE GROWN GaAs. Journal de Physique Colloques, 1982, 43 (C5), pp.C5-135-C5-143. 10.1051/jphyscol:1982517 . jpa-00222236

\section{HAL Id: jpa-00222236 https://hal.science/jpa-00222236}

Submitted on 1 Jan 1982

HAL is a multi-disciplinary open access archive for the deposit and dissemination of scientific research documents, whether they are published or not. The documents may come from teaching and research institutions in France or abroad, or from public or private research centers.
L'archive ouverte pluridisciplinaire HAL, est destinée au dépôt et à la diffusion de documents scientifiques de niveau recherche, publiés ou non, émanant des établissements d'enseignement et de recherche français ou étrangers, des laboratoires publics ou privés. 
JOURNAL DE PHYSIQUE

Colloque C5, supplément au $n^{\circ} 12$, Tome 43, décembre 1982

page $\mathrm{C} 5-135$

\title{
INFLUENCE OF ARSENIC VAPOR SPECIES ON ELECTRICAL AND OPTICAL PROPERTIES OF MBE GROWN GaAs
}

\author{
H. Jung, H. Künzel and $K$. Ploog \\ Max-Planck-Institut für Festkörperforschung, D-7000 Stuttgart 80, F.R.G.
}

\begin{abstract}
Résumé. - L'influence respective des espèces gazeuses de l.'arsenic dimères $\left(A s_{2}\right)$ et Eétramères $\left(\mathrm{As}_{4}\right)$ sur les propriétés électriques et optiques de GaAs, non dopé et dopé par Ge, élaboré par épitaxie de jet moléculaire (MBE.), a été étudiée par effet Ha11, photoluminescence (PL) et mesures DLTS. Le jet moléculaire provenait de deux sources $\mathrm{As}_{2}$ et $\mathrm{As}_{4}$ diffêrentes ainsi que d'une source unique pouvant fournir des rapports de flux $\mathrm{As}_{4} / \mathrm{As}_{2}$ réglables. L'apparition de lignes d'exciton de saut rel iées au défaut dans le spectre $2 \mathrm{~K}$ PL est directement corrêlée à l'existence de trois états profonds (M1, M3, M4), qui sont caractéristiques de GaAs élaboré par 1a méthode MBE. $L$ 'intensité de ces $P L$ lignes supplémentaires et, simultanément la concentration des électrons piégés peuvent être réduites substantiellement par diminution du rapport de $\mathrm{As}_{4}$ sur $\mathrm{As}_{2}$. De plus, un rapport d'autocompensation beaucoup plus faible dans n-GaAs dopé au Ge peut être obtenu par un jet moléculaire d'espèces $\mathrm{As}_{2}$, qui fournit une population de surface de 1 'arsenic nettement plus stationnaire. Les résultats démontrent que 1'incorporation des centres reliés au défaut aussi bien que celle de dopants amphotériques dépend fortement de l'état chimique de la surface impliquéelors du processus de croissance du film.
\end{abstract}

Abstract. - The influence of dimeric $\left(\mathrm{As}_{2}\right)$ vs tetrameric (As $\left.{ }_{4}\right)$ arsenic vapour species on the electrical and optical properties of undoped and of Ge-doped GaAs grown by molecular beam epitaxy (MBE) has been studied by using Hall effect, photoluminescence (PL) and DLTS measurements. The arsenic molecular beam was obtained from separate $\mathrm{As}_{2}$ and $\mathrm{As}_{4}$ sources, resp., and from a single source providing adjustable $\mathrm{As}_{4} / \mathrm{As}_{2}$ flux ratios. The occurrence of the defect related bound exciton lines in the $2 K \mathrm{PL}$ spectra was found to be directly correlated with-the existence of three deep states (M1, M3, M4) which are characteristic of MBE grown GaAs. The intensity of these extra PL lines and simultaneously the electron trap concentration could be reduced substantialiy by decreasing the $\mathrm{As}_{4}$ vs $\mathrm{As} s_{2}$ flux ratio. In addition, a considerably lower autocompensation ratio in Ge-doped $n$-GaAs was achieved with $\mathrm{As}_{2} \mathrm{mo}$ lecular beam species which provide a much higher steady-state arsenic surface population. These results demonstrate that the incorporation of defect related centers as well as of amphoteric dopants strongly depends on the surface chemistry involved in the film growth process.

1. Introduction. - In the growth of GaAs films by molecular beam epitaxy (MBE) the arsenic molecutar beam consists of either tetrameric $\left(\mathrm{As}_{4}\right)$ [1] or dimeric (As $)_{2}$ species [2]. Genera1ly, As ${ }_{4}$ molecular beams produced by evaporating polycrystalline arsenic source material are employed. For the more laborious generation of $\mathrm{As}_{2} \mathrm{mo}^{-}$ lecules during MBE, there are now three methods available: (a) the incongruent evaporation of GaAs source materia] [3], (b) the thermal decomposition of gasecus AsH in a special leak-effusion source [4] or cracking furnace [5], and (c) the cracking of $\mathrm{As}_{4}$ into $\mathrm{As}_{2}$ species in a two-zone effusion cell arrangement $[6,7]$. Previous studies indicated that the quality of MBE GaAs films is probably 
superior when grown from dimeric arsenic species: $[7,8]$. Low-temperature photoluminescence (PL) measurements showed the existence of additional sharp PL lines in the range $1.504-1.511 \mathrm{eV}$ which are due to radiative recombination of bound excitons induced by point defects [8]. The occurrence of these defects was correlated with the complex second-order interaction process of the impinging As $\mathrm{A}_{4}$ molecules on the (100) GaAs growth surface [1]. Except for the line at $1.5109 \mathrm{eV}$, the extra PL features disappeared totally when $A s_{2}$ instead of. $A s_{4}$ beam species were used, thus indicating a substantial decrease of growth induced defects. A comparable reduction of the concentration of deep electron traps in $\mathrm{As}_{2}$-grown MBE GaAs was derived from DLTS measurements [7]

The apparent advantage of $\mathrm{As}_{2}$ over $\mathrm{As}_{4}$ species in MBE of GaAs was attributed to the elementary first-order reaction process of dissociative chemisorption of $\mathrm{As}_{2}$ involving only a single Ga surface atom [2]. This reduces the probability of incorporation of point defects related to $\mathrm{Ga}$ vacancies and their descendants [8]. In addition, it has been speculated that a higher steady-state arsenic surface population during growth exists with $\mathrm{As}_{2}$ beam species. If so, this should also have a strong impact on the incorporation of amphoteric dopants in MBE GaAs.

In this paper we present the results of combined Hall effect, low-temperature PL and DLTS measurements on not intentionally doped and on Ge-doped GaAs layers grown from separate $\mathrm{As}_{4}$ and $A s_{2}$ sources, resp., or from a single source providing adjustable $\mathrm{As}_{4} / \mathrm{As} s_{2}$ flux ratios. In addition to the incorporation of defect related centers, we examine the autocompensation ratio and thereby the site occupancy of the amphoteric dopant Ge. The results are then correlated with the different surface chemistry involved with $\mathrm{As}_{2}$ and $\mathrm{As}_{4}$ molecular beams.

2. Experimental. - The GaAs films were grown in a UHV system of the vertical evaporation type equipped with a sample exchange load-lock device [9]. For the present study we operated four effusion cells to evaporate elemental arsenic, gallium and germanium as well as polycrystalline GaAs. The epitaxial GaAs layers with a thickness of $2 \mu \mathrm{m}$ were deposited without any buffer layer simultaneously onto (10c) criented $\mathrm{Cr}$-doped $\mathrm{SI}$ and heavily $\mathrm{Si}$-doped $\mathrm{N}^{+}$-GaAs substrates. During deposition, the substrate temperature was typically maintained at $550^{\circ} \mathrm{C}$, if not quoted otherwise. The temperatures of the effusion cells containing Ga and elemental arsenic (lower part of the cell only!) or GaAs, resp., were kept constant throughout the growth runs resulting in a constant growth rate of $1.0 \mu \mathrm{m} / \mathrm{h}$ and a constant arsenic-to-ga 71 ium flux ratio of about two, which produces the As-stabilized $(2 \times 4)$ reconstruction on the (100) growth surface. During this study we adjusted the temperature of the Ge effusion cell to yield a constant dpgant flux for a free-electron concentration in the grown layers of between $1 \times 10^{18 \mathrm{~cm}^{-3}}$ and $4 \times 10^{16 \mathrm{~cm}^{-3}}$ depending on the autocompensation ratio.

The elemental arsenic was evaporated in a two-zone $20 \mathrm{~cm}^{3}$ capacity effusion cell made from high-purity quartz glass which has been described in Ref. 10. The two zones could be heated independentiy and their temperatures measured by $W$-Re thermocouples were recorded separately. The temperature of the lower (evaporation) zone determines the total flux, while the temperature of the upper (cracking) zone determines the emerging $\mathrm{As}_{4} / \mathrm{As}_{2}$ ratio. This arrangement made feasibie a very efficient cracking of the evaporating tetrameric species into dimeric species, the amount depending only on the temperature of the removable upper zone. The generation of adjustable $\mathrm{As}_{4} / \mathrm{As}_{2}$ flux ratios from a single source avoids the introduction of any additiona 1 impurities from separate $A \bar{S}_{2}$ and $\mathrm{As}_{4}$ sources. Operation of the cracking zone at temperatures below 500 C yields -a pure $\mathrm{As}_{4}$ flux, whereas operation of that zone at $850{ }^{\circ} \mathrm{C}$ generates a beam consisting of at least $90 \% \mathrm{As}_{2}$. The undoped GaAs films grown from the single elemental arsenic source exhibifed compensated or slightly $n$-type behaviour with electron concentrations below $1 \times 10^{15} \mathrm{~cm}^{-3}$. Even at $8500^{\circ} \mathrm{C}$ cracker temperature there was no measurable influence on the layer quality. After evaluation through $300 \mathrm{~K}$ and $77 \mathrm{~K} \mathrm{Hall}$ effect measurements, the samples were studied by detailed photoluminescence measuremențs at temperatures below $2 \mathrm{~K}$. Excitation was performed by the $6471 \mathrm{~A}$ line of a $\mathrm{Kr}^{+}$laser using a power density of $1 \mathrm{Wcm}^{-2}$. The excitation power was adjusted by neutral density filters. The luminescence light was analysed by a grating monochromator with $1 \mathrm{~A}$ resolution and detected by a photon counting system attached to a cooled GaAs photocathode photomultiplier.

The DLTS measurements of layers grown on $n^{+}$-substrates were performed on $\mathrm{Au}$ 
Schottky barrier diodes using a fully automated measuring system, which has been described elsewhere [11]. During measurement the samples were biased at $-2.0 \mathrm{~V}$. The whole capacitance transient was recorded after applying a short voltage puls of 2.0 $V$ to zero-bias the sample. The emission rates of the electron traps were then calculated from the time constant of the capacitance transient. The temperature dependence of the thermal emission rates yielded the activation energy of the traps and allowed a comparison with data from the literature [12]. The trap concentrations were determined directly from the peak height of the DLTS signal, the total capacitance, and the free-electron concentration as determined by Hail measurements.

3. Resuits and Discussion. -

3.I Photoluminescence Investigations. - Two typical 1ow-temperature PL spectra of MBE GaAs in the near band gap energy region are shown in Fig. 1. The upper spec-

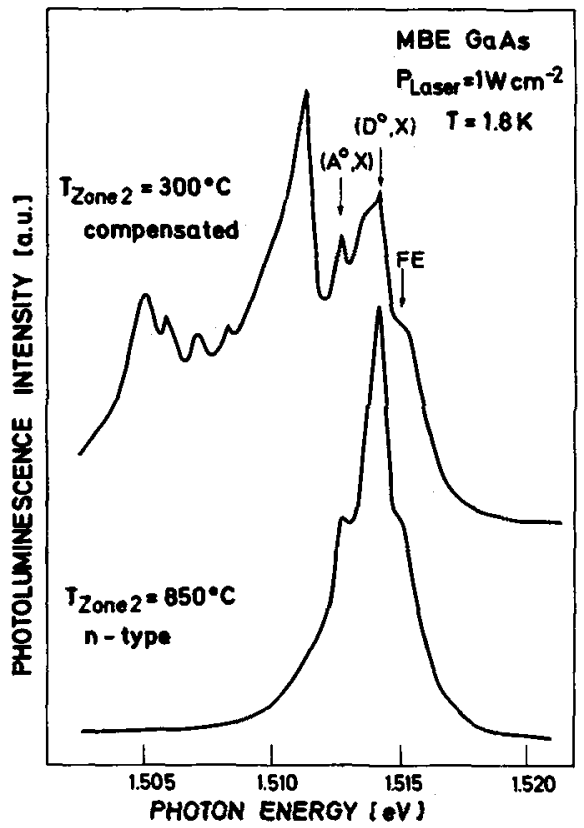
trum was obtained from a nominally undoped GaAs layer grown with the cracking zone of the arsenic effusion cell kept at a temperature of $300^{\circ} \mathrm{C}$. The well-known emission lines of the free exciton, FE, the donor bound-exciton, $\left(D^{\circ}, X\right)$, and the acceptor bound-exciton, $\left(A^{0}, X\right)$, are clearly resolved [13]. In addition, the emission structures at energies below $1.51 \mathrm{eV}$ appear, which have been attributed to defect induced bound excitons [8]. The entire PL spectrum shows thus the same peculiarities as if the sample was grown from a standard onezone $\mathrm{As}_{4}$ source, as shown in Fig. 2.

\section{Fig. 1 : Comparison of $1.8 \mathrm{~K}$ photolumines- cence spectra obtained from nomi- nally undoped MBE GaAs layexs grown from predominantly As 4 (top) and As2 (bottom) molecular beam species of the two-zone effusion cell.}

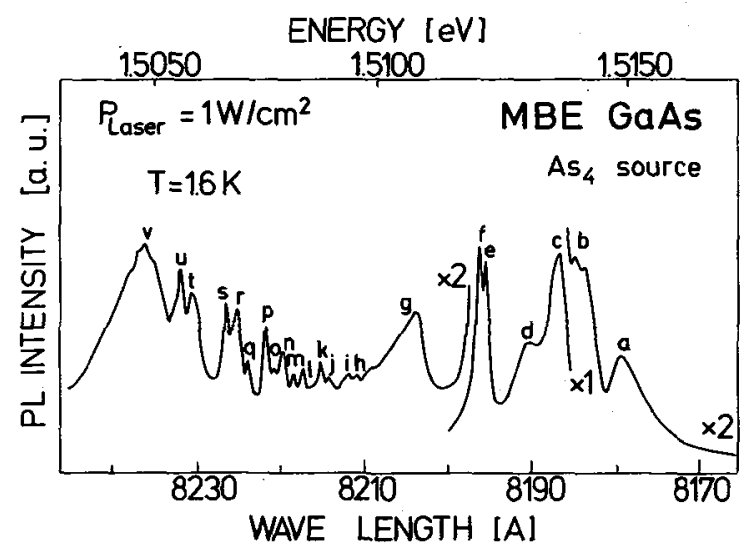

Fig. 2 : Highly resolved $1.6 \mathrm{~K} \mathrm{PL}$ spectrum of a 3 mm thick MBE GaAs layer (p-type) grown from $\mathrm{Ga}$ and $\mathrm{As}_{4}$ species (expanded scale with resolution better than 1 A).

The assignment of the observed spectral features is displayed in Fig. 3.

When the temperature of the cracking zone of the arsenic effusion cell was stepwise increased, however, the PL intensities of the excitonic structures below $1.51 \mathrm{eV}$ were gradually reduced. Inspection of the lower spectrum in $\mathrm{Fig}$. 1 reveals that 


\begin{tabular}{|c|c|c|}
\hline Line & $\begin{array}{l}\text { Energy (ov) } \\
( \pm 0.1 \mathrm{meV})\end{array}$ & Assignment \\
\hline $\begin{array}{l}a \\
b \\
c \\
d \\
\vdots \\
f \\
g \\
h \\
i \\
j \\
k \\
\text { i } \\
\text { m } \\
\text { n } \\
0 \\
\text { p } \\
q \\
\text { f } \\
\text { s } \\
\text { t } \\
u \\
v\end{array}$ & $\begin{array}{l}1.5156 \\
1.5144 \\
1.5140 \\
1.5136 \\
1.5124 \\
1.5122 \\
1.5109 \\
1.5095 \\
1.5093 \\
1.5089 \\
1.5087 \\
1.5084 \\
1.5082 \\
1.5079 \\
1.5077 \\
1.5075 \\
1.5071 \\
1.5069 \\
1.5065 \\
1.5058 \\
1.5056 \\
1.5049\end{array}$ & $\begin{array}{l}\text { free exciton } \\
\text { excited states of }\left(D^{\circ}, X\right) \\
\text { exciton bound to neutral donor }\left(D^{\circ}, X\right) \\
\text { exciton bound to ionized donor }\left(D^{+}, X\right) \\
J=3 / 2 \text { exciton bound to neutral } \\
J=5 / 2 \text { acceptor }\left(A^{*}, X\right)\end{array}$ \\
\hline
\end{tabular}

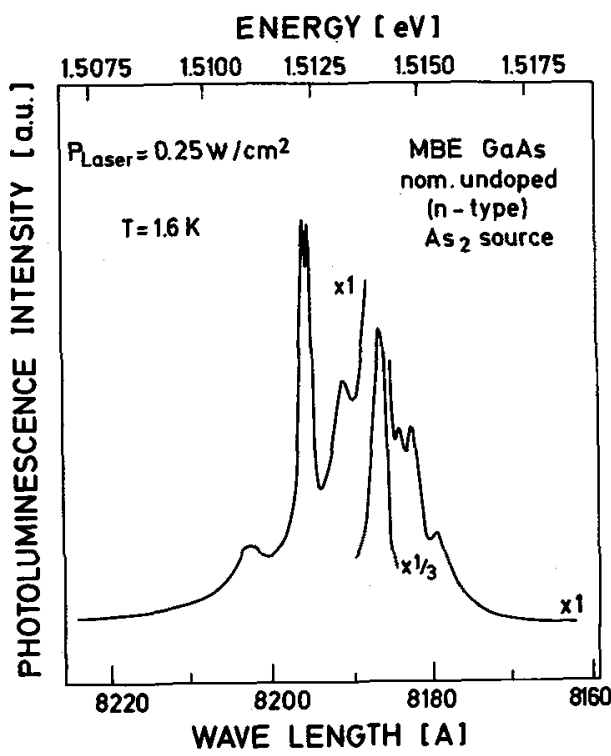

3.2 DLTS Investigations. - The results of our DLTS measurements were used to determine directiy any correlation between the observed continuous reduction of PL intensity due to defect induced bound excitons and the overal1 electron trap concentration as a function of decreasing $\mathrm{As}_{4} / \mathrm{As}_{2}$ ratio in the arsenic molecular beam. For these studies, the samples were intentionaliy doped with germanium. Three typica] DLTS spectra obtained from MBE grown $n$-GaAs:Ge layers are shown in Fig. 5. The DLTS signal was normalized for the spectra of all three samples so that one scale is valid for the trap concentration. The lower spectrum of Fig. 5 was taken from a sample (\#1308) grown with the cracking zone of the effusion cell operated at $500{ }^{\circ} \mathrm{C}$. The observed three dominant features labeled M1, M3, and M4 according to Ref. 12 


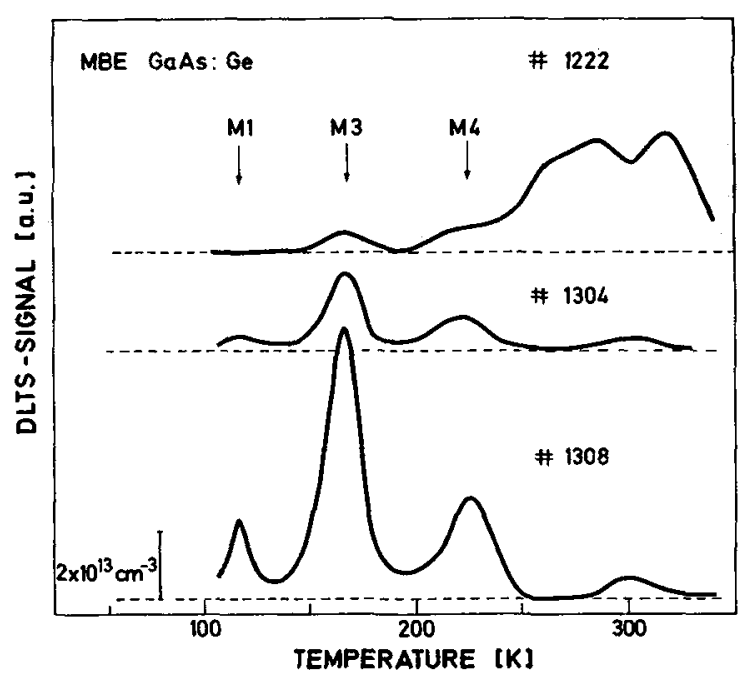

Fig. 5 : DLTS spectra of electron traps in MBE $\mathrm{n}$-GaAs:Ge layers grown with different $\mathrm{As}_{2} / \mathrm{As}_{4}$ flux ratios. The trap concentration scale is the same for all three samples.

are characteristic for MBE GaAs films grown with As-stabilized (2x4) surface reconstruction. At emission temperatures of $300 \mathrm{~K}$. we observed an additional emission structure denoted as M6 electron trap [12]. Inspection of the upper trace in Fig. 5 shows that we could achieve a drastic reduction of the peak heights of the traps $M 3$ and $M 4$, with trap M1 being below the detection limit, when we used pure $A s_{2}$ instead of $A s_{4}$ species from a GaAs source during MBE growth. In addition, an unresolved superposition of several trap signals in the region of the M5, M6 and M7 traps appears, which was also observed by Lang et a1. [12]. Since these features are not sensitive to the applied $\mathrm{As}_{4} / \mathrm{As}_{2}$ ratio and differ from sampie to sample, we considered only the most important traps M1, M3 and M4 for a further systematic study.

Detailed trap concentrations of four MBE n-GaAs:Ge samples grown with different $\mathrm{As}_{4} / \mathrm{As}_{2}$ ratios in the arsenic molecular beam are summarized in rable 1 . lie observed

Table 1. Concentration of M1, M3 and M4 deep levels in MBE n-GaAs:Ge layers with different $\mathrm{As}_{2} / \mathrm{As}_{4}$ molecular beam flux ratios indicated by the temperature ( $\mathrm{T}_{\text {zone }} 2$ ) of the cracking zone

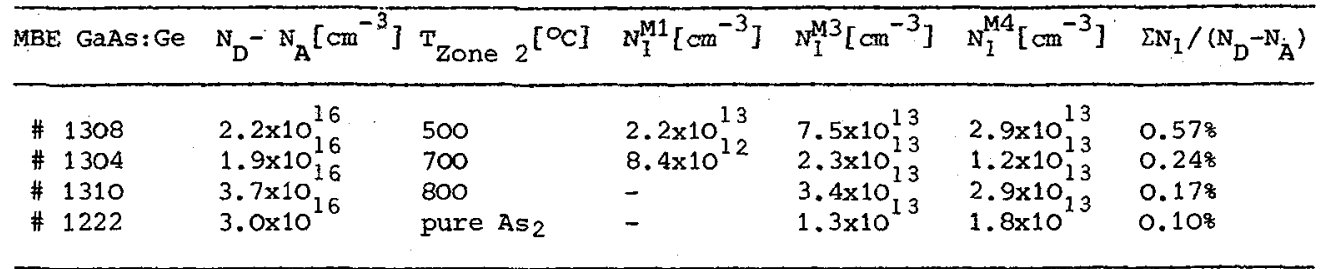

a considerable decrease of the overall concentration of $M 1, M 3$, and $M 4$ traps relative to the free-carrier concentration, when we reduced the tetrameric-to-dimeric ratio of arsenic species by increasing the temperature of the cracking zone. More than a fivefold reduction in trap concentration (M1, M3, M4 was achieved by this procedure. This value could be further reduced to below $10^{-3}$ of the free-carrier concentration by increasing the substrate temperature to $580{ }^{\circ} \mathrm{C}$.

3.3 Investigation of Incorporation. - Next, we performed a more detailed examination of the arsenic surface population during growth by considering the incorporation of Ge impurities. The group-IV-element Ge is an amphoteric dopant in MBE GaAs. 
It has been shown previously $[15,16]$ that the Ge incorporation depends critically on the Ga and As sites available on the growing GaAs surface, i.e. on the appl ied $\mathrm{As}_{4} / \mathrm{Ga}$ flux ratio and on the substrate temperature. Therefore, the measurable ratio of autocompensation $\left[\mathrm{Ge}_{A S}\right] /\left[\mathrm{Ge}_{\mathrm{Ga}_{2}}\right]$, where $\left[\mathrm{Ge}_{A \mathrm{~A}}\right]$ is the concentration of $\mathrm{Ge}$ acceptors

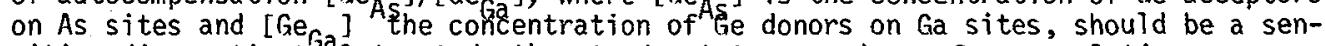
sitive diagnostic tor 1 to study the steady-state arsenic surface population as a function of impinging dimeric and tetrameric arsenic species.

For a first qualitative estimation of this effect, Fig. 6 displays two shallow

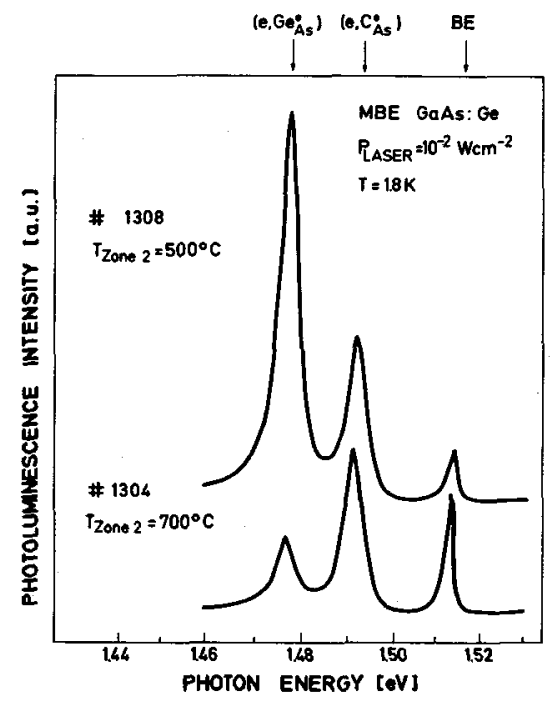

Fig. 6: : Shallow acceptor $1.6 \mathrm{~K}$ PL spectra of MBE n-GaAs:Ge layers grown with different $\mathrm{As}_{2} / \mathrm{As}_{4}$ flux ratios. The spectra are normalized in intensity to the peak height of the $\left(e, A^{\circ}\right)$ transition related to $\mathrm{C}_{\mathrm{As}}$.

acceptor PL spectra of intentionally Ge-doped n-type GaAs films grown with different temperatures of the $\mathrm{As}_{4}$ cracking zone. In both spectra the two acceptors Ge As $_{\text {s }}$ and $C_{A s}$ can be clearly detected by their Asecombination radiation $\left(e, A^{O}\right)$ of free electrons e captured at the corresponding neutral acceptors $A^{O}$. An increase of the amount of $\mathrm{As}_{2}$ relative to $\mathrm{As}_{4}$ species emerging from the arsenic source results in a marked reduction of the $\left(e, A^{O}\right)$ luminescence transition related to Ge on As sites at $1.479 \mathrm{eV}$. The considerable decrease of the $\left(e, A^{0}\right)$ intensity occurs at a cracker temperature of $700{ }^{\circ} \mathrm{C}$. This is in good agreement with the behaviour of the defect induced bound exciton lines described in Sec. 3.1. The dimeric arsenic species replacing the tetrameric ones in the reaction provide a considerable higher arsenic surface population at the same arsenic-to-gallium flux ratio and substrate temperature. This drastically reduces the amount of As sites available for Ge incorporation on acceptor sites.

Based on a model including both $C$ and Ge acceptors as well as Ge donors we could recently show [17] that the ratio of Ge autocompensation decreases exponentially with inverse substrate temperature, as depicted by the upper curve of Fig. 7 , when using Ga and $\mathrm{As}_{4}$ molecular beams. The data of the temperature dependence of the $\mathrm{Ha} 17$ effect yielded the overall compensation ratio, $N_{A} / N_{1}$, and the data from detailed PL measurements were used to estimate the ratio of $P$ ' and $G e$ acceptors incorporated on As sites. From that analysis we were thus able to determine the concentration of the three dominant impurities $\left[\mathrm{Ge}_{\mathrm{G}}\right],\left[\mathrm{Ge}_{A s}\right]$, and $\left[\mathrm{C}_{A s}\right]$ separately.

then we applied the same evaluation procedure to Gâs: Ge samples grown from dimeric arsenic species only (generated by incongruent evaporation of GaAs), we obtained the concentrations summarized in Table 2. Ue also observed an exponential decrease of the Ge autocompensation ratio with inverse substrate temperature. Inspection of $\mathrm{Fig}$. 7 reveals, however, that a much lower and therefore more favourable compensation ratio in $n-G a A s: G e$ can be achieved at a given substrate temperature with the use of $\mathrm{As}_{2}$ instead of $\mathrm{As}_{4}$ species. Autocompensation ratios as low as $2 \times 10^{-2}$ have been obtained at a substrate temperature of $530{ }^{\circ} \mathrm{C}$ (of course this value does not include the additional compensating ( $\mathrm{C}$ acceptors). The observed behaviour of autocompensation of amphoteric dopants in MBE GaAs is thus directly correlated with the surface population of available free As sites for acceptor incorporation which can be more drastically reduced by an external flux of dimeric than tetrameric 
arsenic species.

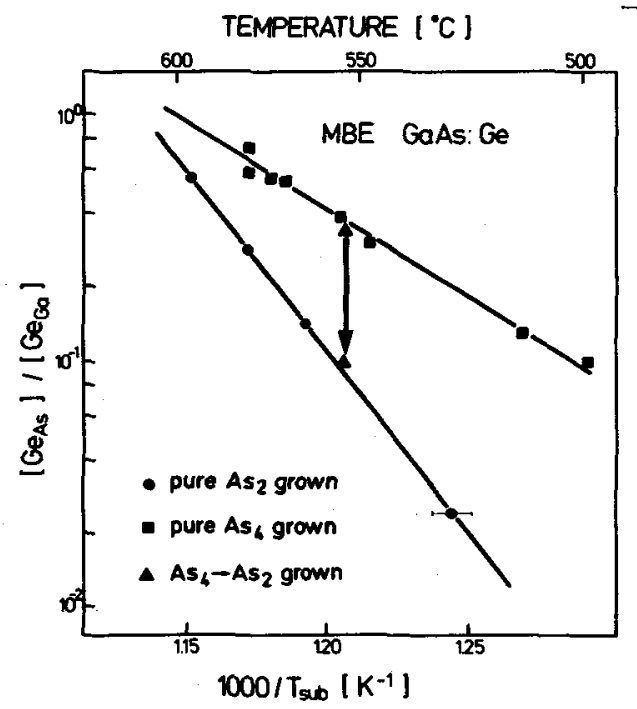

Fig. 7 : Substrate temperature dependence of Ge autocompensation ratio in $\mathrm{MBE}$ n-GaAs: Ge layers;

- samples grown from pure As4 molecular beam species by evaporation of elemental arsenic.

- samples grown from pure $\mathrm{As}_{2}$ molecular beam species by incongruent evaporation of GaAs.

- samples grown from an adjustable $\mathrm{As}_{2} / \mathrm{As}_{4}$ ratio in the molecular beam by operating the two-zone effusion cell. The arrow indicates the reduction of autocompensation by increasing the $\mathrm{As}_{2} / \mathrm{As}_{4}$ flux ratio.

Table 2. Concentration of $\mathrm{C}$ and Ge impurities on either Ga or As sites in MBE GaAs: Ge layers grown from pure As $\mathrm{A}_{2}$ molecular beam species at different substrate temperatures. Growth at $610^{\circ} \mathrm{C}$ produces p-type material where the analysis of Hall data is not valid

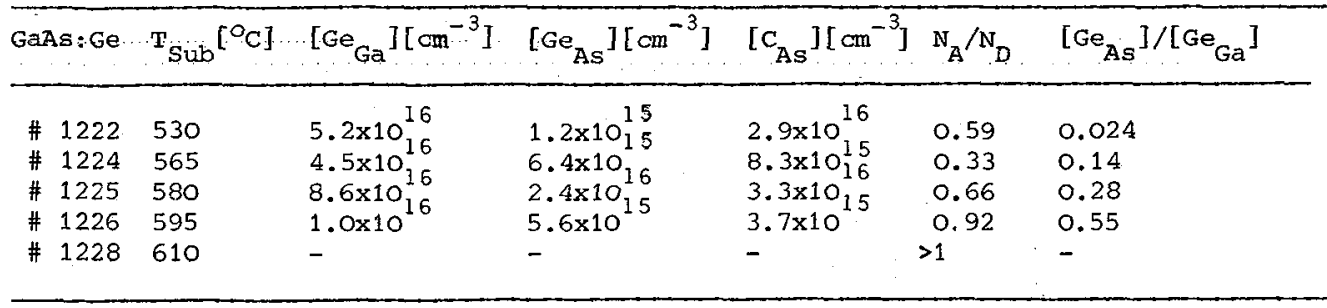

The other striking result indicated in Fig. 7 is that, nevertheless, with both arsenic species the transition of MBE GaAs:Ge layers, grown at a constant arsenicto-gallium flux ratio of two, from n-type to p-type material occurs in the same substrate temperature range of $600-610^{\circ} \mathrm{C}$. The observed behaviour agrees well with earlier results of Neave and Joyce [18] in that the surface population of vacancies for $\mathrm{Ge}$ incorporation does not only relate to the external fluxes but is also influenced by the internal sources of both Ga and As. This reevaporation of the constituent elements from the growing surface depends strongly on the growth temperature. An increase of the substrate temperature at constant incident fluxes lowers the ratio of arsenic-to-galifum steady state adatom population, unti] at $\mathrm{T}_{\text {Sub }}>600{ }^{\circ} \mathrm{C}$ a

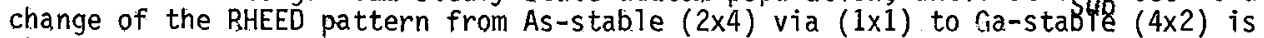
obseryed.

Finally; we demonstrate that the observed difference of Ge autocompensation is not caused by any additional impurities from the separate $A s_{2}$ and $A s_{4}$ sources. The black triangles in Fig. 7 indicate the results of two representative samples (\# 1304 and \# 1308) which were grown with different $\mathrm{As}_{4} / \mathrm{As}_{2}$ ratios generated from 
the two-zone effusion cel1. A reduction of the Ge autocompensation ratio from 0.34 (\# 1304) to 0.10 (\# 1308), indicated by the arrow in Fig. 7 , has been achieved simply by increasing the temperature of the $\mathrm{As}_{4}$ cracking zone to $700{ }^{\circ} \mathrm{C}$, where dimeric arsenic beam species dominate. This behaviour is consistent with the results of our $\mathrm{PL}$ measurements described earlier in the text.

4. Conclusion. - The optical and electrical properties of undoped and of Ge-doped MBE GaAs Tayers were studied as a function of the impinging arsenic molecular beam species. Tetrameric molecules ( $\mathrm{As}_{4}$ ) were obtained by standard evaporation of elemental arsenic, whereas dimeric molecules $\left(A_{2}\right)$ were generated either by incongruent evaporation of GaAs in a separate source or by cracking of $\mathrm{As}_{4}$ in a single two-zone effusion ce11. The results of combined Hall effect, low-temperature PL and DLTS measurements demonstrate that a direct correlation exists between the arsenic species used and the incorporation of point defects as well as of amphoteric dopants.

The low-temperature PL measurements confirm that our previous observation of defect induced bound exciton lines is indeed caused by the interaction of tetrameric arsenic species and not by any external impurity from separate source materials needed for $\mathrm{As}_{2}$ and $\mathrm{As}_{4}$. The intensity of those extra emission 1 ines between 1.504 and $1.511 \mathrm{eV}$ can be reduced to below the detection limit by cracking As 4 into $\mathrm{As}_{2} \mathrm{spe}_{4}$ cies in a single two-zone effusion cell arrangement.

The behaviour of the intensity of the defect related PL emission lines was found to be directly correlated with the concentration of three deep states (1:11, M3, 144) which are characteristic of MBE GaAs films grown under As-stabilized $(2 \times 4)$ surface reconstruction. The concentration of the electron traps due to defect related deep centers may be easily modified by changing the impinging $\mathrm{As}_{4} / \mathrm{As}_{2}$ flux ratio via the cracker temperature. Thus, a substantial reduction by a factor of five has been achieved, when a pure dimeric arsenic source is used.

Furthermore, we point out that the incorporation of point defect related centers as well as of amphoteric doping impurities is particularly sensitive to the surface chemistry involved. While $\mathrm{As}_{2}$ species impinging on the growing (100) GaAs surface undergo a rather elementary process of dissociative chemisorption (first-order process) involving a single Ga surface atom [2], the $\mathrm{As}_{4}$ species must encounter a pairwise interaction of relatively bulky units adsorbed on adjacent pairs of $\mathrm{Ga}$ surface atoms [1]. As a consequence, the steady-state arsenic surface concentration is much higher with impinging $\mathrm{As}_{2}$ than with $\mathrm{As}_{4}$, al1 other growth conditions including the observed surface reconstruction being constant. This reduces considerably the amount of vacancies responsible for native defect formation as well as free As sites available for Ge incorporation as acceptors. In good accordance with our results on the intensity of the extra PL lines and on the concentration of deep traps we obtained substantially lower autocompensation ratios in Ge-doped n-GaAs samples using $A s_{2}$ instead of $\mathrm{As}_{4}$ as a source of arsenic.

For amphoteric dopant incorporation in MBE. GaAs it is finally important to notice that the surface population of vacancies available for site occupation during growth does not only depend on the external fluxes but also on the internal sources of re-evaporating gallium and arsenic. While in agreement with Teramoto's theory [19] an external flux of $\mathrm{As}_{4}$ has only a minor influence on the slope of the autocompensation ratio $\left[\mathrm{Ge}_{A s}\right] /\left[\mathrm{Ge}_{\mathrm{Ga}}\right]$ versus $1 / \mathrm{T}$ plot, the external flux of $\mathrm{As}_{2}$ yields a much steeper slope of that felation indicating its strong influence on the steadystate surface population of free As sites available for Ge acceptor incorporation. This is a direct consequence of the increased growth surface coverage with arsenic arising from the rather elementary surface chemistry involved.

Acknowledgement. - This work was sponsored by the Bundesministerium fuir Forschung und Technologie of the Federal Republic of Germany. 


\section{References}

[1] FOXON C.T. and JOYCE B.A., Surf. Sci. 50 (1975) 434.

[2] FOXON C.T. and JOYCE. B.A., Surf. SCi. 64 (1977) 293.

[3] FOXON. C.T., HARYEY J.R., and JOYCE B.A., J. Phys. Chem. Solids 34 (1973) 1693.

[4] PANISH M.B., J. Electrochem. Soc. 127 (1980) 2729.

[5] CALAWA A.R., Appl. Phys. Lett. 38 (1981) 701.

[6] CHO A.Y. and HAYASHI I., Solid State Electron. 14 (1971) 125.

[7] NEAVE J.H., BLOOD P., and JOYCE B.A., App1. Phys. Lett. 36 (1980) 311.

[8] KONIZEL H. and PLOOG K., App1. Phys. Lett. 37 (1980) 416.

[9] PLOOG K., in CRYSTALS, GROWTH, PROPERTIES, AND APPLICATIONS ed. FREYHARDT H.C. (Berlin-Heidelberg: Springer, 1980) 73.

[10] KONZEL H., KNECHT J., JUNG H., WONSTEL K., and PLOOG K., Appl. Phys. A28 (1982) 167.

[11] MAGNER E.E., HILLER D., and MARS D.E., Rev. Sci. Instrum.51 (1980) 1205.

[12] LANG D.V., CHO A.Y., GOSSARD A.C., ILEGEMS M., and WIEGMFiNN W., J.Appl.Phys. $47(1976) 2558$.

[13] HEIM 11. and HIESINGER P., Phys. Stat. So1. (b) 66 (1974) 461.

[14] SCOTT G.B., DUGGAN G., DAWSON P., and WEIMANN G., J. Appl. Phys. 52 (1981) 6888.

[15] CHO A.Y., and HAYASHI I., J. Appl. Phys, 42 (1971) 4422.

[16] WOOD C.E.C., WOODCOCK. J., and HARRIS J.J., Inst. Phys. Conf. Ser. No. $\underline{45}$ (1979) 28.

[17] KONZEL H., FISCHER A., and PLOOG K., AppT. Phys. 22 (1980) 23.

[18] NEAVE J.H. and JOYCE B.A., J. Cryst. Growth 44 (1978) 387.

[19] TERAMOTO I., J. Phys. Chem. Sotids 33 (1972) 2089. 